CT 診断が有用であった子宮広間膜異常裂孔へルニアの 1 例

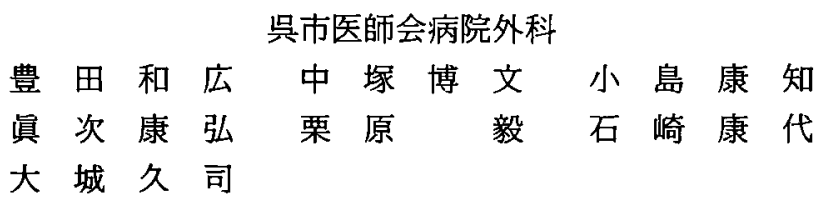

イレウスの原因として内ヘルニアは多くはないが，このなかでも非常に稀な子宮広間 膜異常裂孔に生じた内へルニアを経験した。症例は77歳, 女性で腹痛, 嘔吐を主訴に入 院した. CT 検查にて拡張した小腸により右子宮広間膜が伸展・厌排され，子宮も左側に 王排されており，子宮広間膜異常裂孔ヘルニア嵌頓が強く疑われた。卵管結禁術の既往 があり, 瘾着性イレウスも否定できず保存的加療開始したが, 軽快せず子宮広間膜異常 裂孔ヘルニア嵌頓による絞扼性イレウスと判断し手術を施行した．開腹すると，右子宮

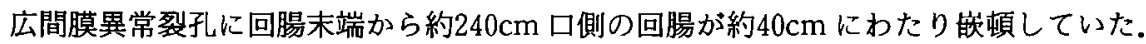
嵌頓した小腸は壊死を来しており，子宮円索および子宮広間膜を切離し嵌頓を解除後壊 死小腸を切除した。本疾患の術前診断は困難であるが，われわれの症例では術前 CT 検 査が大変有用であった，原因のはっきりしないイレウスに対しては CT 検查は重要と考 えられた。

索引用語：子宮広間膜ヘルニア, 内ヘルニア, イレウス

\section{緒言}

内ヘルニアは比軽的稀な疾患であり，そのなかでも 子宮広間膜異常裂孔に生じた内へルニアは非常に稀て ある。本疾患の術前猃断は困難である゙が，今回われわ れは本疾患の 1 例を経験し術前 CT 検査が大変有用で あったので，若干の文献的考察を加え報告する。

\section{症 例}

患者：77歳, 女性.

主訴：腹痛および澏吐.

既往歴：33歳時, 卵管結禁術。妊娠歷 6 回（正常分 婏 4 回, 人工流産 2 回).

家族歴：特記すべきことなし.

現病歴：平成 11 年 1 月 3 日より腹痛および嘔吐が出 現した。 1 月 5 日に近医を受診し，イレウスと診断さ れ，同日精查加療目的で当科へ紹介入院となった。

入院時現症：身長 $153 \mathrm{~cm}$, 体重 $51 \mathrm{~kg}$, 体温 $35.4^{\circ} \mathrm{C}$, 脈拍 $94 /$ 分・整, 血圧 $92 / 60 \mathrm{mmHg}$. 眼瞼結膜に軽度貧 血を認めた。腹部は膨隆し, 右下腹部に压痛を認めた。 腸雑音は聴取されなかった。下腹部正中には約 $7 \mathrm{~cm}$

1999年 8 月12日受付 1999年10年14日採用
の手術痕を認めた。また直腸診は特に異常は認めなか った.

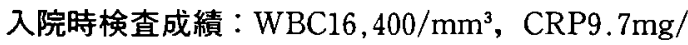
$\mathrm{dl}, \mathrm{BUN} 35.1 \mathrm{mg} / \mathrm{dl}$ と上昇しており，炎症および脱水 の存在が示唆された。また CPK が58U と軽度上昇(正 常：5〜50U) していた. その他 RBC $458 \times 10^{4} / \mathrm{mm}^{3}$, $\mathrm{Hb} 12.1 \mathrm{~g} / \mathrm{dl}, \mathrm{Hct} 37.9 \%$ で督血はなく, 肝機能, アミ ラーゼなども正常範囲であった。

入院後経過：1月 5 日入院時腹部単純 $\mathrm{X}$ 線にて鏡面 形成を伴う小腸ガス像を認めたが，結腸のガス像は䚾 とんど認めなかった(図 1)．腹部 CT 検查では主とし て空腸の拡張がみられた。また，骨盤腔内の拡張した 小腸により右子宮広間膜が伸展・圧排され，子宮も左 側に圧排されていた(図2)。このCT 所見より右子宮 広間膜異常裂孔へルニア嵌頓が強く疑われたが, 卵管 結禁術の既往があり，瘾着性イレウスも完全には否定 できないため，イレウス管を挿入し保存的加療開始し た。しかし，1月 7 日イレウス管により小腸の拡張は 減少したが，右下腹部に拡張の残った小腸を腫溜様に 触知するようになり，右子宮広間膜異常裂孔へルニア 嵌頓による较抳性イレウスと判断し，手術を施行した。 


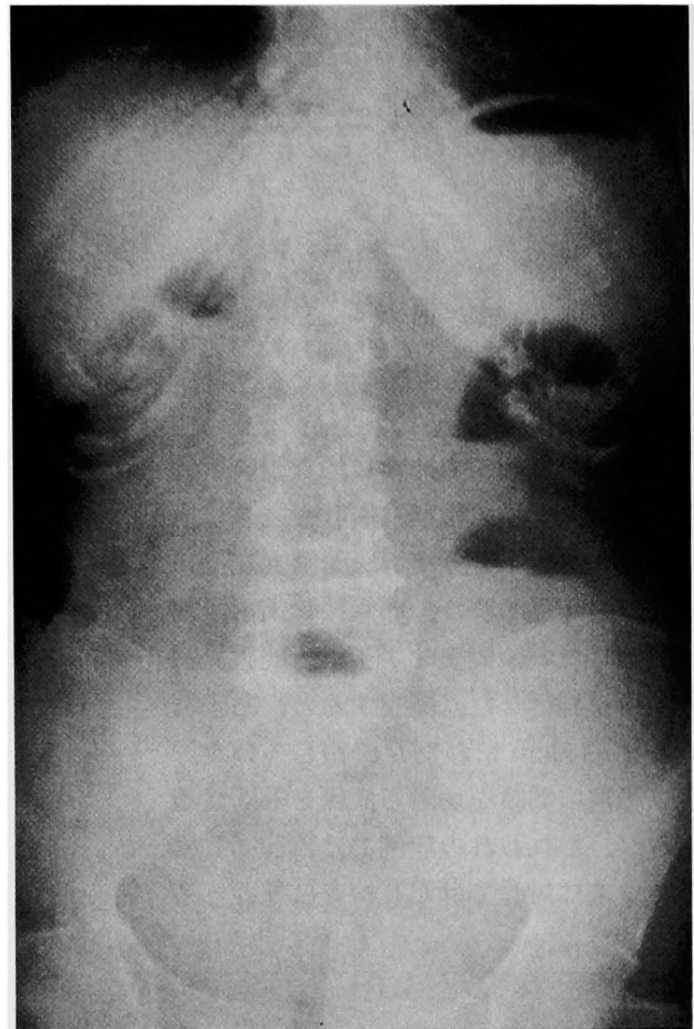

図 1 入院時腹部単純 X 線：鏡面形成を伴う小腸ガス 像を認めた。

手術所見：全身麻酔下に下腹部正中切開で開腹し た. 腹腔内に腹水を少量認めた，腹腔内を詳細に観察 すると回腸末端から約 $240 \mathrm{~cm}$ 口側の回腸が約 $40 \mathrm{~cm} に$ わたり右子宮広間膜異常裂孔に腹側から背側に嵌頓し ていた(图 3 ). 嵌頓した小腸は壤死を来しており，子 宮円索および子宮広間膜を切離し(図 4), 嵌頓を解除 後壊死小腸を切除吻合した。なお，左の子宮広間膜に は異常を認めなかった。また卵管結热術による痹着は はっきりしたものはなかった。

術後経過：術後経過は良好で術後19日目に退院し た.

\section{考䕓}

イレウスの原因には様々なものがあるが，内ヘルニ アは臨床上稀な疾患であり，イレウス全体からみると 約 $1 \%$ 前後の頻度とされている ${ }^{2}$. Steinke の分類 ${ }^{3)}$ は内ヘルニアは腹膜後へルニアと異常裂孔へルニアに 大別され，さらに異常裂孔へルニアは腸間膜異常裂孔 ヘルニア, 大小網異常裂孔ヘルニアおよび子宮広間膜 異常裂孔ヘルニアの 3 つに分類されている。このなか
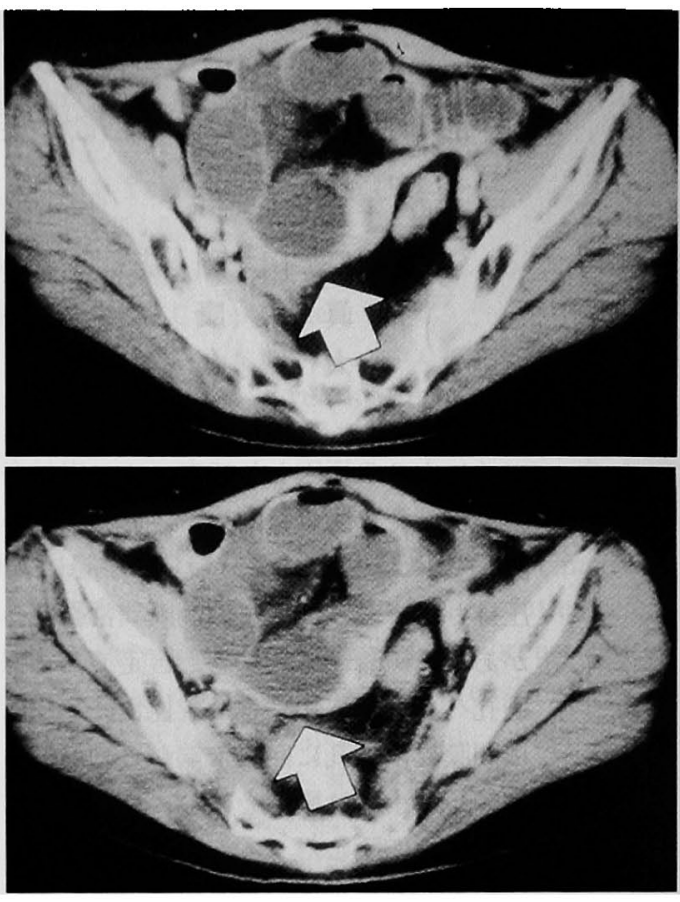

図 2 腹部 CT 検査：拡張した小腸により右子宮広間膜 が伸展・圧排され (矢印), 子宮も左側に圧排されてい た.

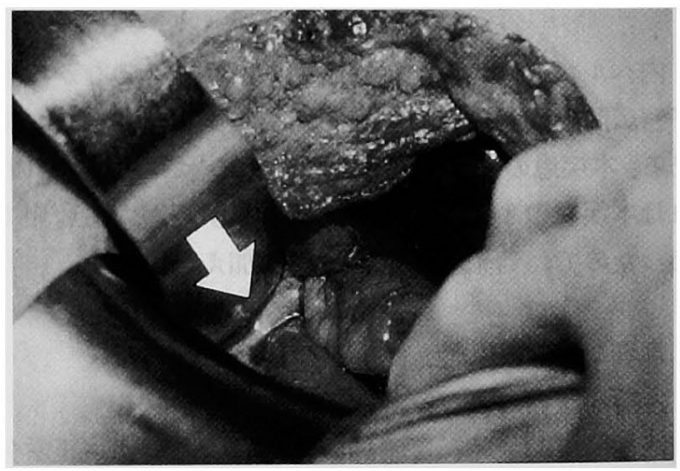

図 3 術中所見：小腸が右子宮広間膜の異常裂孔（矢 印）に麻頓していた。

でも子宮広間膜異常裂孔ヘルニアは非常に稀であり， これまで国内では30数例が報告されているのみであ $ろ^{4)}$.

子宮広間膜の異常裂孔の成因としては，先天奇形， 弤娠・分婏による裂傷，炎症性疾患に起因寸る欠損， 婦人科手術の影響などが推測されている(5)6). 欧米の報 告では53例の子宮広間膜裂孔ヘルニアのうち19例が 


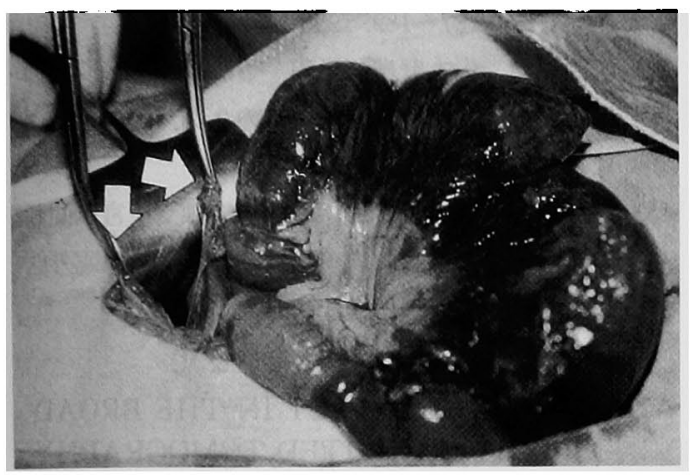

図 4 術中所見：子宮円索を切離し(矢印)，岸頓を解除

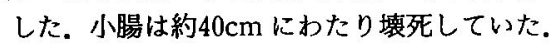

Webster-Baldy の子宮固定術術後に発生していると の文献集計結果が出されている7.この WebsterBaldy 手術は子宮後屈に対して以前行われていた手術 で，子宮広間膜を通して子宮円索を引き出し固定する 方法であり，子宮広間膜が損傷されるのは明らかで後 に子宮広間膜裂孔へルニアを発症しても不思議はな い. 本症例には子宮後屈に対する手術既往はないもの の，卵管結禁術の既往があり，両側卵管間膜および反 対側の子宮広間膜に異常はなかったが，この時の手術 操作による損傷も考えられる。しかし本症例を含めて これまで報告された症例のほとんどが経産婦であり， 妊娠・分婏による裂傷を原因とするのが最も考えやす w.

一般的に内ヘルニアの術前診断は困難なことが多 く，原因不明の絞扼性イレウスとして開腹手術となる ことも少なくない. 子宮広間膜異常裂孔へルニアも同 様に術前診断は困難であり，ほとんどの症例が絞扼性， 瘜着性などのイレウスの診断で開腹され，その術中に 子宮広間膜異常裂孔へルニアと診断されている。しか し内ヘルニアに扔いてもCT 検査は術前診断に重要で あり ${ }^{8)}$ ，子宮広間膜異常裂孔ヘルニアの報告例でも術 前 CT 検査の有用性を指摘する報告も散見され る499-11).これらの報告では子宮広間膜裂孔へルニア のCT 像の特徴として Douglas 窩に拡張腸管が存在 すること，およびこれによる子宮の圧排所見を挙げて いる。かれわれの症例でも同様な所見が得られたのみ ならず，伸展・圧排された子宮広間膜も描出され本垁 患を強く疑わせた。しかし，本症例には卵管結禁術を 受けた既往があり，この手術による瘾着などの影響を 完全には否定できなかったため，CT 検査施行当日手 術は行わずイレウス管を挿入し経過をみた。もし卵管
結染の既往がなければ確帮に診断できCT 検査当日緊 急手術となっていたと思われる.

治療に関しては嵌頓の解除ちよび壊死腸管があれば 切除吻合するといった一般的なへルニア嵌頓の治療と 変わるところはないが，両側に異常裂孔が存在した報 告もあり ${ }^{1113)}$ 反対側の子宮広間膜に異常のないこと を確認することも重要であろう。

\section{結語}

術前 CT 検査が有用であった子宮広間膜異常裂孔に 生じた内ヘルニアの1例を経験した. 原因のはっきり しないイレウスの診断においては内ヘルニアも念頭に 置きCT 検查を施行することが必要である．また経産 婦の原因不明のイレウスに遭遇したときは，本疾患も 鑑別疾患として考えるべきであろう。

本論文は要旨は第54回日本消化器外科学会総会（1999年 7 月, 名古屋) において発表した。

\section{文 献}

1）豊田和広, 小川喜輝, 有田道典 他: 子宮広間膜巽 常裂孔に生じた内へルニアの 1 例. 日臨外会誌 $60: 216-219,1999$

2) 庄司佑, 渋谷哲男, 秋丸琥甫：イレウス。 II. 各論. 和出達雄監修, 新外科学大系, $25 \mathrm{~B}$, 中山書 店, 東京, 1990, p259-310

3) Steinke CR : Internal hernia. Three additional case reports. Arch Surg 25: 909-925, 1932

4) 諏訪勝仁, 柵瀨信太郎, 大東誠司他：CT 診断が有 用であった子宮広間膜へルニアの 1 例. 日臨外会 誌 $59: 1654-1658,1998$

5) Hunt B:Fenestra and pouches in the broad ligament as an actual and potential cause of strangulated intra-abdominal harnia. Surg Gynecol Obstet 58:906-913, 1934

6）唐澤幸彦, 武田智博, 前場隆志：右子宮広間膜裂 孔ヘルニアの 1 例. 日臨外会誌 $59: 2385-2389$, 1998

7) Simstein NL: Internal herniation through a defect in the broad ligament. Am Surg $53: 258$ $-259,1987$

8）渡邊公伸, 栗谷義樹, 諸星保憲他：内ヘルニアの 4 例とそのCT像について. 消外 $22: 1159-$ 1164,1999

9) Suzuki M, Takashima $T$, Funaki $H$, et al: Radiologic imaging of herniation of the small bowel through a defect in the broad ligament. 
Gastrointest Radiol $11: 102-104,1986$

10）益崎隆雄, 白井善太郎, 鳥谷 裕他：術前 CT 検 查にて診断し得た小腸嵌入子宮広間膜裂孔ヘルニ アの 1 例. 福岡大医紀 $20: 29-32,1993$

11) Ishihara $H$, Terahara $M$, Kigawa $J$, et al : Strangulated herniation through a defect of the broad ligament of the uterus. Gynecol Obstet
Invest $35: 187-189,1993$

12）松山茂樹, 山本賢輔, 黒田 豊他：子宮広間膜の 異常裂孔に生じた内ヘルニアの 2 例. 臨外 37 ： $1291-1294,1982$

13）荻野敦弘，稲葉征四郎，近藤雄二他：子宮広間膜 の異常裂孔に生じた内へルニアの 1 例. 日臨外医 会誌 $55: 1297-1300,1994$

\title{
A CASE OF INTERNAL HERNIATION THROUGH AN ABNORMAL DEFECT IN THE BROAD LIGAMENT OF THE UTERUS SUCCESSFULLY DIAGNOSED BY COMPUTED TOMOGRAPHY
}

\author{
Kazuhiro TOYOTA, Hirofumi NAKATSUKA, Yasutomo OJIMA, \\ Yasuhiro MATSUGU, Takeshi KURIHARA, Yasuyo ISHIZAKI \\ and Hisashi OSHIRO \\ Department of Surgery, Kure City Medical Association Hospital
}

\begin{abstract}
Internal hernia is not a common cause for intestinal obstruction. Among of those hernias, a very rare internal herniation through an abnormal defect in the broad ligament of the uterus is reported. A 77-year -old woman was admitted to the hospital because of abdominal pain and vomiting. CT examination demonstrated that the uterus deviated to the left and the right broad ligament was extended due to the distended small intestine. An internal herniation through a defect in the broad ligament suspected, but there was a history of undergoing an operation for ligation of the uterine tube and adhesive ileus was also probable. The patient was treated conservatively with a long tube, but no symptomatic remission was obtained. So, a strangulated herniation through a defect of the right broad ligament of the uterus was diagnosed and an operation was performed. At laparotomy, the ileum, approximately $40 \mathrm{~cm}$ in length and $240 \mathrm{~cm}$ proximal to the ileocecal valve, was herniated through an abnormal defect in the broad ligament of the uterus. Right round ligament was cut and the incarceration was reduced. This disease presents difficulty in preoperatively diagnosis, but CT examination is helpful in diagnosis. When we encounter patients with intestinal obstruction of unknown origin, CT examination must be performed.
\end{abstract}

